特許와 論文으로 본 텅스텐카바이드(WC) 再活用 技術 動向 ${ }^{\dagger}$

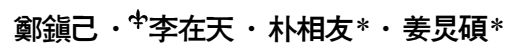

韓國地質資源研究院，*시온텍 技術研究所

\title{
Trend on the Recycling Technologies for the used Tungsten Carbide(WC) by the Patent and Paper Analysis ${ }^{\dagger}$
}

\author{
Jinki Jeong, *Jae-chun Lee, Sang-woo Park* and Kyung-Seok Kang* \\ Korea Institute of Geoscience \& Mineral Resources(KIGAM) 30 Gajeong-dong, Yuseong-gu, Daejeon, 305-350 Korea \\ *Siontech Co., Ltd. 530 Yongsan-dong, Yuseong-gu, Daejeon 305-500, Korea
}

\section{요 약}

텅스텐카바이드는 금속절단 공구, 드릴의 날, 광산공구, 군사무기 재료, 화학원료, 촉매, 내마모성재료, 제트엔진 터빈 블레이드 등 다양한 용도로 사용된다. 요즘 경제적인 측면과 효율적인의 측면에서 텅스텐카바이드 재활용 기술이 넓게 연구되었다. 이 논문에서 는 텅스텐카바이드 재활용 기술에 대하여 1969년부터 2011년까지 공개/등록된 미국, 일본, 유럽, 한국의 특허와 SCI급 논문을 조사 하였다. 키워드를 이용하여 조사하였고 필터링 하여 특허와 논문을 수집하여 연도별, 국가별, 기관별, 기술별로 분석하였다.

주제어 : 텅스텐카바이드, 재활용, 특허, 논문, 분석, 기술 동향

\begin{abstract}
There are several kinds of tungsten carbide(WC) such as light bulbs, metal cutting tools, drill bits, mining tools, military ordinance, high speed tool steels, chemicals/catalysts, wear resistance parts, jet engine turbine blades, etc.. These days it has been widely studied for the recycling technologies of the used tungsten carbide(WC) from view points of economy and efficiency. In this paper, open/registered patents of US, JP, EP, and KR and SCI Journal related to recycling technologies of the used Tungsten Carbide(WC) between 1969 2011 were reviewed. Patents and papers were collected using key-words searching and filtered by filtering criteria. The trends of the patents and papers was analyzed by the years, countries, companies, and technologies.
\end{abstract}

Key words : Tungsten Carbide(WC) recycling, patent, paper, analysis, Technical trend

\section{1. 서}

초경소재는 산업전반에 널리 사용되고 있으며 텅스텐 카바이드(WC)의 경우 알려진 금속 가운데 다이아몬드 다음으로 단단한 물질로 금속 절단 공구, 드릴의 날, 광 산 공구, 군사 무기 재료, 화학 원료, 촉매, 내마모성 재료 및 제트엔진 blade에 이용되고 있다. $\mathrm{WC} / \mathrm{Co}$ 초 경합금은 $\mathrm{WC}$ 와 $\mathrm{Co}$ 를 주성분으로 하고, 여기에 $\mathrm{TiC}$,

†2011년 9월 30일 접수, 2011년 11월 9일 1차수정
2011년 12월 9일 수리
†E-mail: jclee@kigam.re.kr

$\mathrm{TaC}$ 등의 일부 탄화물이 첨가된 소재로 경도가 매우 높고 내마모성이 우수하여 내마모 공구, 내충격 공구, 연삭기 및 금형 소재 등으로 널리 사용되고 있다. 이러 한 초경재료 제품을 사용하는 과정에서 부서지거나 부 러지고 수명이 다한 스크랩이 발생하게 된다. 그리고 초 경재료를 이용한 공구 및 제품을 제조하는 과정에서 많 은 양의 슬러지가 발생하게 된다.

이러한 초경 스크랩 및 슬러지는 많은 양의 WC 및 $\mathrm{Co}$ 등의 이용 가능한 자원을 다량 함유하고 있어 이러 한 스크랩 및 슬러지를 재활용하는 것은 자원의 유효이 용 측면에서 매우 중요하며 경제적인 가치도 충분히 가 
지고 있는 것으로 사료된다.,2)

연구에 앞서, 특허/논문 분석에 의한 기술동향 파악은 기존에 수행되었던 관련기술의 연구내용뿐만 아니라, 향 후 연구의 방향을 설정하는데 중요한 자료로 활용되고 있 으며, 연구내용이 중복되는 것을 사전에 막아주는 역할을 한다. 이에 본 연구에서는 텅스텐카바이드의 재활용 기술 에 대하여 일본, 미국, 유럽 그리고 한국의 특허정보와 논 문정보를 분석함으로서 기술의 동향을 파악하고자 하였다.

\section{2. 기술의 분류 및 정의}

\section{1 기술의 분류}

텅스텐카바이드(WC) 재활용 기술을 Table 1과 같이 크게 대분류에 따라 습식, 건식, 전처리로 나누고 소분 류에 따라 습식은 산처리, 알칼리처리, 전기분해, $\mathrm{FeCl}_{3}$ 침지, 건식은 산화/환원, 아연법, 용융, cold stream, reduction and carbidizing, 전처리는 분쇄, 코팅제거로 각각 분류하였다. ${ }^{2-6)}$

\section{2. 기술의 정의}

대부분의 텅스텐카바이드(WC) 스크랩은 습식법을 이 용한 재활용이 가능하다. 주로 텅스텐카바이드(WC) 스 크랩으로부터 고순도의 암모늄파라텅스테이트를 제조하 여 초경합금의 원료로 다시 사용하는 재활용 방법으로, 불순물이 포함되어 있는 오염된 스크랩의 재활용에도 사용이 가능하며 공정이 단순하고 에너지 효율이 좋으 나 환경오염을 초래할 수 있고 물의 공급이 원활한 곳 에서 적용이 가능하다는 단점이 있다.

산화/환원법은 가공슬러지가 $800^{\circ} \mathrm{C}$ 부근에서 공기에 의하여 쉽게 산화되는 점을 이용하는 방법으로 산화된 슬러지는 분쇄와 체질을 거쳐서 $900 ~ 1000^{\circ} \mathrm{C}$ 에서 수소 환원함으로서 텅스텐 분말을 회수하는 방법이고, 아연 법은 금속아연 $(\mathrm{Zn})$ 을 사용하여 탄화물과 코발트 분말을 회수하는 방법이다. 아연법, 산화/환원, cold stream법은 에너지 소비와 이차 폐기물의 발생이 적으며, 낮은 생 산 비용으로 처리가 가능하다는 장점이 있지만, 스크랩 이 불순물이 없고 순도가 높을 때만 제한적으로 활용이 가능하다는 단점이 있다. ${ }^{4)}$

\section{3. 특허/논문검색대상 및 분석 기준}

\section{1. 특허 / 논문검색 대상}

본 연구에서는 Table 2와 같이 1969년부터 2011년
Table 1. processes used in the recycling of used Tungsten Carbide(WC)

\begin{tabular}{|c|c|c|}
\hline 기술 & 대분류 & 소분류 \\
\hline \multirow{13}{*}{$\begin{array}{c}\text { 텅 스텐 카바이드 (WC) } \\
\text { 재활용 기술 }\end{array}$} & \multirow{5}{*}{ 습식 } & 산처리 \\
\hline & & 알칼리처리 \\
\hline & & 전기분해 \\
\hline & & $\mathrm{FeCl}_{3}$ 침지 \\
\hline & & 기타 \\
\hline & \multirow{6}{*}{ 건식 } & 산 화/환원 \\
\hline & & 아연법 \\
\hline & & 용융 \\
\hline & & cold stream \\
\hline & & reduction and carbidizing \\
\hline & & 기타 \\
\hline & \multirow{2}{*}{ 전처리 } & 분쇄 \\
\hline & & 코팅제거 \\
\hline
\end{tabular}

Table 2. Analysis period and Database

\begin{tabular}{|c|c|c|c|c|}
\hline & 국가 & 분석기간 & 정보원 & 대 상 (건) \\
\hline \multirow{4}{*}{ 특허 } & 한국 & \multirow{4}{*}{$\begin{array}{c}\text { 1969년 } \\
\text { 2011년 4월 }\end{array}$} & \multirow{4}{*}{ Wips DB } & 22건 \\
\hline & 일본 & & & 29건 \\
\hline & 유럽 & & & 10 건 \\
\hline & 미국 & & & 33건 \\
\hline 논문 & - & $\begin{array}{c}\text { 1980년 } \\
\text { 2011년 4월 }\end{array}$ & Scopus & 76건 \\
\hline
\end{tabular}

4월까지의 공개/등록된 특허와 1980년부터 2011년 4월 까지의 논문을 수집하여 사전작업을 걸쳐 최종 분석 데 이터를 구축하였다.

한국 및 일본, 유럽은 특허 출원 후 1년 6개월 이후 에 공개되는 특허제도의 특성상, 2009년 이후에는 미공 개 특허가 존재하므로 데이터 신뢰기간은 2008년까지 가능한 것을 밝힌다.

\section{2. 데이터 구축}

$\mathrm{DB}$ 구축은 Fig. 1과 같이 4단계로 나누어 볼 수 있 다. 텅스텐카바이드(WC) 재활용 기술 관련 키워드의 조 합식을 사용하여 수집된 원 데이터(raw data)는 International Patent Classification(IPC), 각 기술의 정의 등의 기준에 의해 94 건의 분석 대상 특허와 76 건의 분석 대상 논문을 추출하였다. 분석 대상 특허/논문은 기술분 


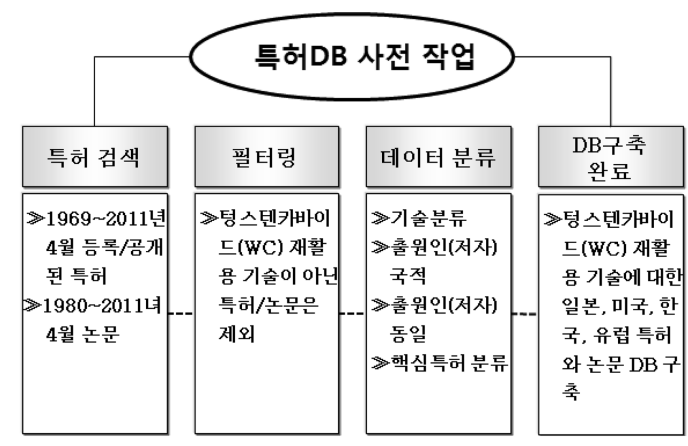

Fig. 1. Flow-sheet for database setup.

류, 동일 출원인 명칭통일, 출원인 국적, 핵심특허 분류 등의 사전작업을 통하여 $\mathrm{DB}$ 구축을 완료하였다.

\section{4. 거시적 동향 분석}

\section{1 전체 특허 / 논문 동향}

전체 특허/논문 동향을 알아보기 위해서 Fig. 2와 같 이 전체 연도별 특허출원과 논문발표 건수 및 누적 건 수를 그래프로 나타내었다. 특허의 경우, 증가와 감소가 반복적으로 나타나고 있으며 1970년대 중반부터 1980 년대 중반까지 매년 5건 이하의 특허가 꾸준히 출원되 다가, 1996년에 특허가 급격히 증가하여 1990년대 후 반까지 활발한 특허활동을 보이고 있으며, 2000년대 후 반에도 활발한 특허활동을 보이고 있다. 그래프 상에서 2010년 특허출원 건수가 감소하는 것은 출원된 특허들 의 많은 수가 아직 심사단계에 있으며 공개 되지 않았 기 때문이다.

논문의 경우 특허와 마찬가지로 증가와 감소가 반복 적으로 나타나고 있으며 2000년대 중반에 가장 활발한 논문발표를 보이고 있고, 2005년에는 가장 많은 10 편 의 논문을 발표하였다.

\section{2. 국가별 특허/논문 동향}

국가별 특허/논문 동향을 살펴보기 위해 Fig. 3은 전 체 국가별 특허출원과 논문발표 현황 및 점유율을 나타 낸 그래프이다. 미국이 특허와 논문 모두에서 각각 29 건(30.9\%)과 17건(17.7\%)으로 텅스텐카바이드(WC) 재활용 기술에서 가장 높은 순위를 나타내고 있으며 일 본이 특허 25건(26.6\%), 논문 9건( $11.4 \%)$ 으로 2위 와 3 위에 나타나며 한국이 특허에서 3 위로 나타나고 있 지만 논문의 경우 미국, 일본에 비해 매우 낮은 점유율

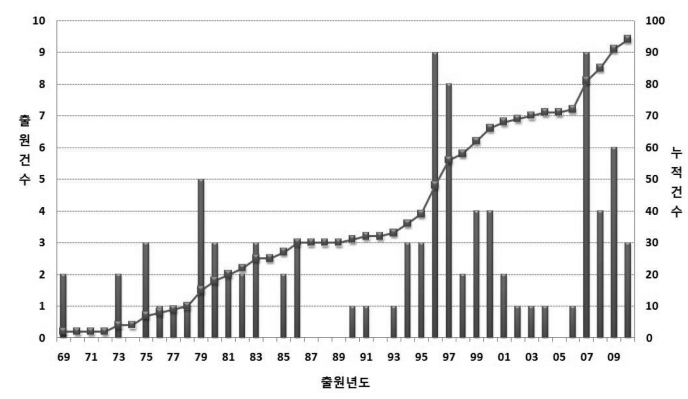

(a) patent

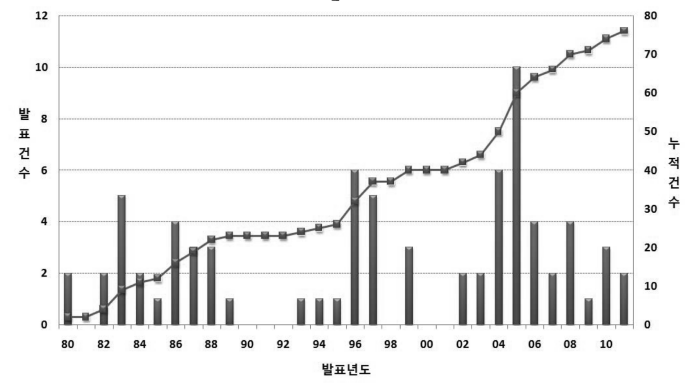

(b) paper

Fig. 2. A trend of the patents and papers yearwise.

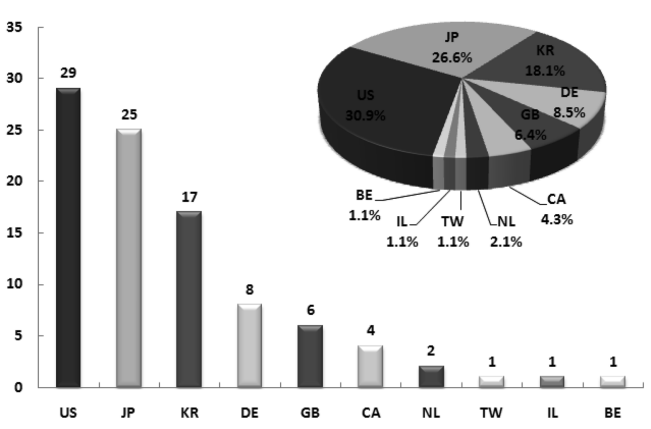

(a) patent

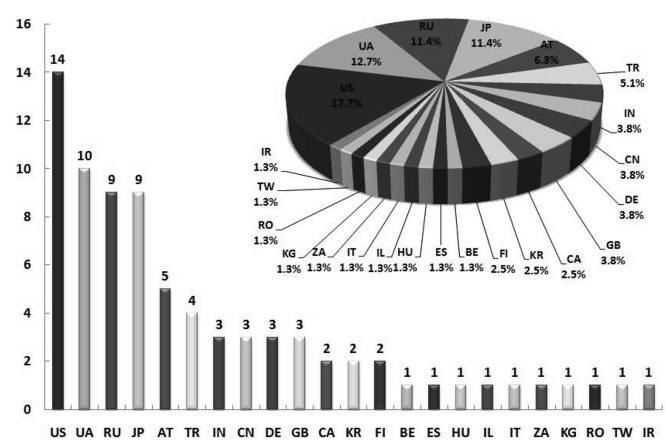

(b) paper

Fig. 3. Number and share of patents and papers by countrywise. 
을 나타내고 있다. 우크라이나와 러시아의 경우 특허의 분석 $\mathrm{DB}$ 가 미국, 일본, 유럽, 한국특허만을 대상으로 하 여 $\mathrm{DB}$ 에 포함되어 있지 않기 때문에 특허출원 현황은 나타나고 있지 않지만 논문발표에서 각각 10 건(12.7\%), 9건(11.4\%)으로 높은 점유율을 나타내고 있다.

\section{3. 출원인별 특허와 논문 동향}

Fig. 4는 특허와 논문의 주요출원인 및 주요기관 현 황을 나타낸 것이다. 특허의 경우, 주요 출원인의 특허 출원이 전체 특허출원에서 차지하는 비율이 $58.1 \%$ 로 비교적 높으며, 기타 출원인들은 모두 1 2건 정도의 특 허출원을 하였다.

미국의 GTE(현 Osram Sylvania)가 13건으로 가장 많은 특허를 출원하였고, 독일의 H.C. Starck와 미국의 Nanodyne Inc.이 각각 8건, 영국의 Interox Chemicals 가 6 건의 순으로 나타났다. 주요출원인 10 위까지의 출 원인 중 미국이 3 개 기관으로 가장 많았으며 일본과 한 국이 일반인을 포함하여 각각 2 개 기관, 독일, 영국, 캐

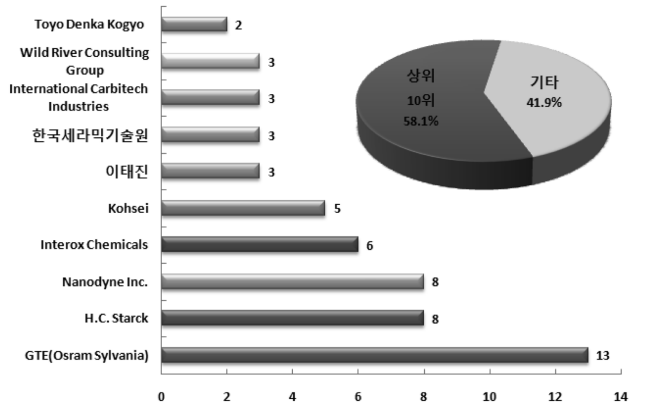

(a) patent

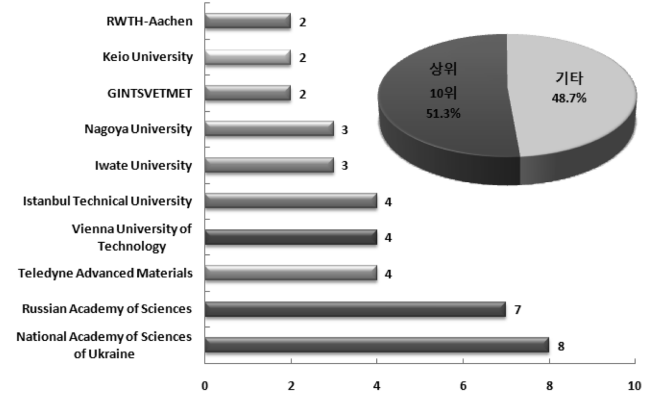

(b) paper

Fig. 4. Number and share of patents and papers by the applicant.
나다가 1 개 기관으로 확인되었다. 반면 논문의 경우 특 허에서는 조사되지 않은 우크라이나의 National Academy of Sciences of Ukraine가 8건으로 가장 많 은 논문을 발표하였고, 러시아의 Russian Academy of Sciences가 7건, 미국의 Teledyne Advanced Materials, 오스트리아의 Vienna University of Technology, 터키 의 Istanbul Technical University가 각각 4건의 순으로 나타났다. 상위 10 위권 내의 발표기관을 살펴보면 일본 이 3 개 기관으로 가장 많았으며 러시아가 2개 기관, 우 크라이나, 미국, 오스트리아, 터키, 독일이 1 개 기관으로 확인되었다

가장 많은 특허를 출원한 GTE(현 Osram Sylvania) 은 1981년 아연법을 이용하여 텅스텐을 회수하는 1 건 의 특허를 제외하고는 1973 년부터 1991년까지 12 건의 특허를 습식 기술에 관하여 출원하였다.

\section{4. 기술별 특허와 논문 동향}

텅스텐카바이드(WC) 재활용 기술은 크게 건식, 습식, 전처리 기술로 나눌 수 있다. 특허출원 건수를 나타낸 Fig. 5(a)를 살펴보면, 습식 기술에 대한 특허가 61건으

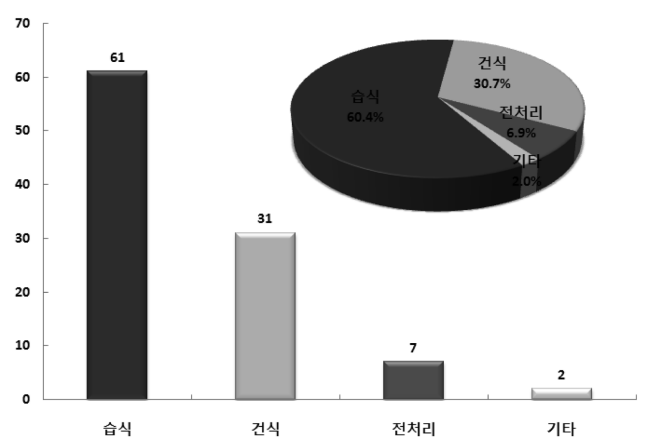

(a) patent

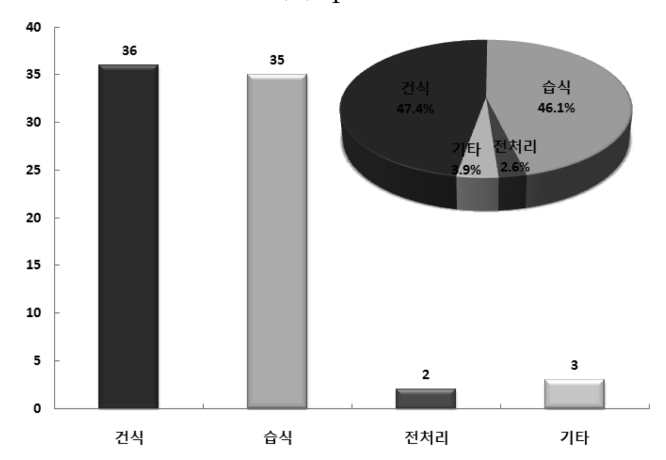

(b) paper

Fig. 5. Number of patents and papers in each technology. 
Table 3. Number of patents and papers by technologies in the different countries

\begin{tabular}{|c|c|c|c|c|c|c|c|c|}
\hline \multirow{5}{*}{ Countries } & \multicolumn{4}{|c|}{ Patent } & \multicolumn{4}{|c|}{ Paper } \\
\hline & \multirow{4}{*}{ 습식 } & 산 & \multirow{4}{*}{ 건식 } & 용융 & \multirow{4}{*}{ 습식 } & 산 & \multirow{4}{*}{ 건식 } & 용융 \\
\hline & & 알칼리 & & 산 화 / 환 원 & & 알칼리 & & 산 화 / 환 원 \\
\hline & & 전기분해 & & 아연법 & & 전기분해 & & 아연법 \\
\hline & & others & & others & & others & & others \\
\hline \multirow{4}{*}{ US } & \multirow{4}{*}{22} & 9 & \multirow{4}{*}{7} & - & \multirow{4}{*}{6} & 2 & \multirow{4}{*}{8} & 1 \\
\hline & & 10 & & 5 & & 1 & & - \\
\hline & & 3 & & 2 & & 3 & & 5 \\
\hline & & - & & - & & - & & 2 \\
\hline \multirow{4}{*}{ JP } & \multirow{4}{*}{14} & 5 & \multirow{4}{*}{6} & 2 & \multirow{4}{*}{4} & 4 & \multirow{4}{*}{5} & - \\
\hline & & 3 & & 3 & & - & & 1 \\
\hline & & 5 & & 1 & & - & & 2 \\
\hline & & 3 & & - & & - & & 2 \\
\hline \multirow{4}{*}{$\mathrm{KR}$} & \multirow{4}{*}{6} & 4 & \multirow{4}{*}{7} & 2 & \multirow{4}{*}{1} & 1 & \multirow{4}{*}{1} & - \\
\hline & & - & & 3 & & - & & - \\
\hline & & 2 & & 2 & & - & & - \\
\hline & & - & & - & & - & & 1 \\
\hline \multirow{4}{*}{$\mathrm{DE}$} & \multirow{4}{*}{4} & - & & 8 & & 2 & & \\
\hline & & 4 & 8 & - & 2 & - & & \\
\hline & & - & 0 & - & 2 & - & & \\
\hline & & - & & - & & - & & \\
\hline & & & & & & - & & - \\
\hline IA & & & & & 3 & - & 7 & 1 \\
\hline UA & & & & & 3 & 3 & 1 & - \\
\hline & & & & & & - & & 6 \\
\hline & & & & & & 3 & & - \\
\hline PU & & & & & 7 & - & $?$ & - \\
\hline KU & & & & & 1 & 2 & 2 & 1 \\
\hline & & & & & & 2 & & 1 \\
\hline & & 6 & & & & & & - \\
\hline $\mathrm{GP}$ & 6 & - & & & & & 2 & - \\
\hline UD & 0 & - & & & & & 2 & 1 \\
\hline & & - & & & & & & 1 \\
\hline & & 4 & & 3 & & & & \\
\hline $\mathrm{CA}$ & 4 & - & 3 & - & & & & \\
\hline & & - & & - & & & & \\
\hline & & - & & - & & & & \\
\hline & & & & & & 1 & & 2 \\
\hline AT & & & & & 1 & - & 4 & - \\
\hline & & & & & & - & & - \\
\hline & & & & & & - & & 2 \\
\hline
\end{tabular}

J. of Korean Inst. Resources Recycling Vol. 21, No. 1, 2012 
Table 3. Continued

\begin{tabular}{|c|c|c|c|c|c|c|c|c|}
\hline \multirow{5}{*}{ Countries } & \multicolumn{4}{|c|}{ Patent } & \multicolumn{4}{|c|}{ Paper } \\
\hline & \multirow{4}{*}{ 습식 } & 산 & \multirow{4}{*}{ 건식 } & 용융 & \multirow{4}{*}{ 습식 } & 산 & \multirow{4}{*}{ 건식 } & 용융 \\
\hline & & 알칼리 & & 산 화 / 환 원 & & 알칼리 & & 산 화 / 환 원 \\
\hline & & 전기분해 & & 아연법 & & 전기분해 & & 아연법 \\
\hline & & others & & others & & others & & others \\
\hline \multirow{4}{*}{ TR } & & & & & \multirow{4}{*}{4} & 3 & & \\
\hline & & & & & & 1 & & \\
\hline & & & & & & - & & \\
\hline & & & & & & - & & \\
\hline \multirow{4}{*}{ IN } & & & & & \multirow{4}{*}{3} & 1 & & \\
\hline & & & & & & - & & \\
\hline & & & & & & 2 & & \\
\hline & & & & & & - & & \\
\hline \multirow{4}{*}{$\mathrm{CN}$} & & & & & \multirow{4}{*}{2} & 1 & \multirow{4}{*}{1} & - \\
\hline & & & & & & - & & - \\
\hline & & & & & & 1 & & - \\
\hline & & & & & & - & & 1 \\
\hline
\end{tabular}

로 전체의 $60.4 \%$ 를 차지하고 있으며, 건식 기술이 31 건으로 $30.7 \%$, 전처리 기술이 7 건으로 $6.9 \%$ 의 점유 율을 보이고 있다. 논문발표 건수를 나타낸 Fig. 5(b)를 살펴보면, 36 건으로 전체의 $47.4 \%$ 를 차지하고 있으 며, 습식 기술이 35 건으로 $46.1 \%$, 전처리 기술이 2 건으로 $2.6 \%$ 의 점유율을 보이고 있다.

출원인 및 저자 국적별 특허와 논문건수를 비교해보 면 논문의 경우 미국, 일본은 습식과 건식 기술에 유사 한 점유율을, 우크라이나, 영국, 오스트리아는 건식기술 에, 독일, 러시아, 터키, 인도는 습식 기술에서 높은 점 유율을 보이는 것으로 나타났다. 특허의 경우 한국, 캐 나다는 습식과 건식 기술에 대해 유사한 점유율을, 미 국, 일본, 영국은 습식 기술에, 독일은 건식 기술에 대해 높은 점유율을 보이는 것으로 나타난다. 이를 Table 3에 정리하였다. 기술별 자세한 분석은 심층적 동향 분석에 서 다룰 것이다.

\section{5. 심층적 동향 분석}

\section{1. 습식 기술 특허와 논문동향}

Fig. 6은 특허와 논문의 습식 기술 대한 세부기술별 동향을 나타낸 것이다. 특허의 경우, 산처리 30 건 (46.9\%)과 알칼리처리 18 건(28.1\%)에 관련된 특허가 대

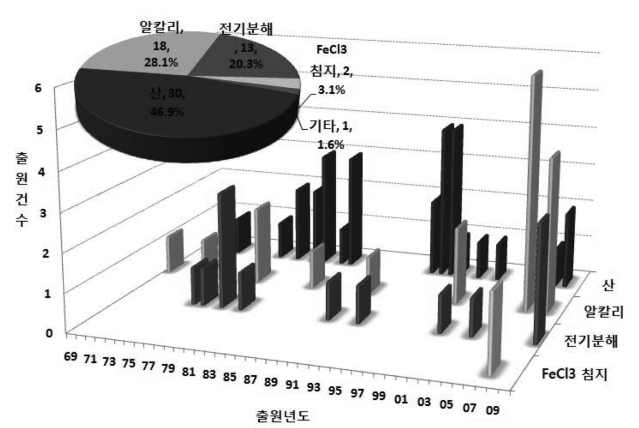

(a) patent

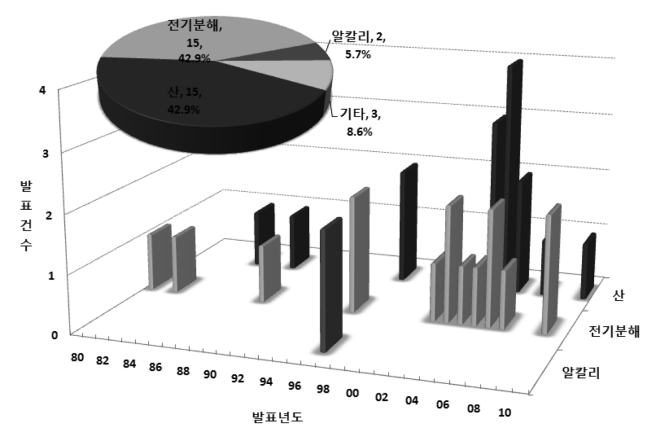

(b) paper

Fig. 6. A trend of patents and papers yearwise in each hydrometallurgical technology. 
부분으로 나타났으며, 전기분해 13 건(20.3\%), $\mathrm{FeCl}_{3}$ 침지 2건(3.1\%) 등의 순서로 나타났다.

산처리 기술은 1980 년대와 1990 년대 중반에 가장 활 발한 특허 활동을 하고 있고, 알칼리처리 기술은 2007 년에 독일의 H.C. Starck와 미국의 Wild River Consulting Group가 집중적으로 특허를 출원하여 가장 많은 6건의 특허가 출원되는 등 2000년대 중반이후 활 발한 특허활동을 하고 있는 것으로 나타났다. 전기분해 기술은 1979년과 2010년에 가장 많은 특허를 출원하였 고, $\mathrm{FeCl}_{3}$ 침지 기술은 가장 늦은 2008년에 2건의 특 허를 처음 출원하였다.

논문의 경우, 산처리, 전기분해 15 건(42.9\%), 알칼리 처리 2 건 $(5.7 \%)$ 등의 순서로 나타나며, 1980 년 전기 분해에 관한 논문이 가장 먼저 발표된 이후 2000년대 중반에 산처리 기술과 전기분해에 관한 논문이 활발하 게 발표되었다.

Fig. 7은 특허와 논문의 주요출원인 및 주요기관 현 황을 나타낸 것이다. 특허의 경우, 주요 출원인의 특허 출원이 전체 특허출원에서 차지하는 비율이 $71.1 \%$ 로 높으며, 기타 출원인들은 모두 1 2건 정도의 특허출원 을 하였다.

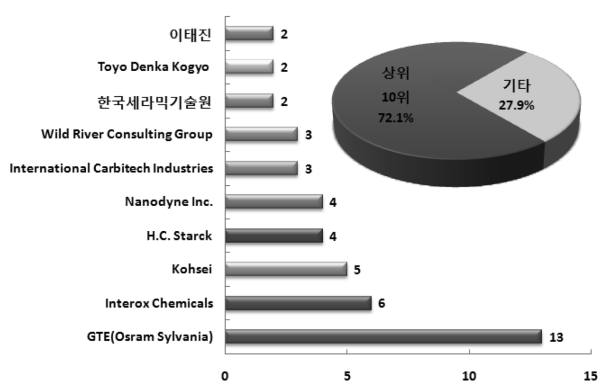

(a) patent

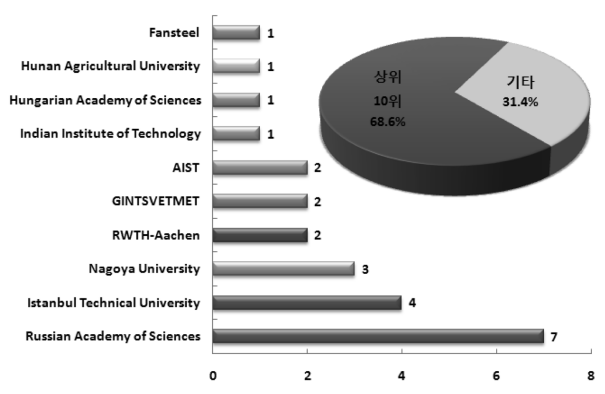

(b) paper

Fig. 7. Number and share of patents and papers in hydrometallurgy by the applicant.
미국의 GTE(현 Osram Sylvania)가 13건으로 가장 많은 특허를 출원하였고, 영국의 Interox Chemicals가 6건, 일본의 Kohsei가 5건, 독일의 H.C. Starck과 미국 의 Nanodyne Inc.이 각각 4건의 순으로 나타났다. 주 요출원인 10 위까지의 출원인 중 미국이 3 개 기관으로 가장 많았으며 일본과 한국이 일반인을 포함하여 각각 2 개 기관, 독일, 영국, 캐나다가 1 개 기관으로 확인되었 다. 반면 논문의 경우 러시아의 Russian Academy of Sciences가 7건으로 가장 많은 논문을 발표하였고, 터키 의 Istanbul Technical University가 4건, 일본의 Nagoya University가 3 건의 순으로 나타났다. 상위 10 위권 내의 발표기관을 살펴보면 러시아, 일본이 2 개 기관으로 가 장 많았으며 터키, 독일, 헝가리, 중국, 미국이 1 개 기 관으로 확인되었다

가장 많은 특허를 출원한 GTE(현 Osram Sylvania) 는 산처리, 알칼리처리, 전기분해 기술 등 습식 기술의 세부 기술에 모두 주요 출원인으로 나타나고 있으며, Interox Chemicals은 산처리 기술에 가장 많은 특허를 출원하였고, Kohsei는 전기분해, H.C. Starck은 알칼리 처리에 많은 특허를 출원하였다. Russian Academy of Sciences는 산처리와 전기분해 기술, Istanbul Technical University는 산처리와 알칼리 기술, Nagoya University 는 산처리 기술에 많은 논문을 발표하였다.

\section{2. 건식 기술 특허와 논문동향}

Fig. 8은 특허와 논문의 건식 기술 대한 세부기술별 동향을 나타낸 것이다. 특허의 경우, 용융이 15 건 (48.4\%)으로 가장 높은 점유율을 보이며 산화/환원 11 건(35.5\%), 아연법 5 건(16.1\%)의 순서로 나타났다.

아연법 관련 특허가 가장 먼저 출원이 이루어졌으며 산화/환원 기술은 1975 년에 1 건의 특허가 출원되었고 1990년 중반 이후 활발한 특허활동을 보이고 있다. 용 융 기술은 가장 늦은 1994년에 처음으로 출원되었고 1990 년대 중반에 가장 활발한 특허활동을 보인다.

논문의 경우, 아연법 14 건(36.8\%), reduction and carbidizing 8 건(21.1\%), 산화/환원 3건(7.9\%), cold stream과 용융이 각각 2건(5.3\%) 등의 순서로 나타나며, 1980 년 아연법에 관한 논문이 가장 먼저 발표된 이후 1980년대에 가장 활발하게 논문을 발표하였다.

Fig. 9는 특허와 논문의 주요출원인 및 주요기관 현 황을 나타낸 것이다. 특허의 경우, 주요 출원인의 특허 출원이 전체 특허출원에서 차지하는 비율이 $77.4 \%$ 로 높으며, 기타 출원인들은 모두 1건 정도의 특허출원을 


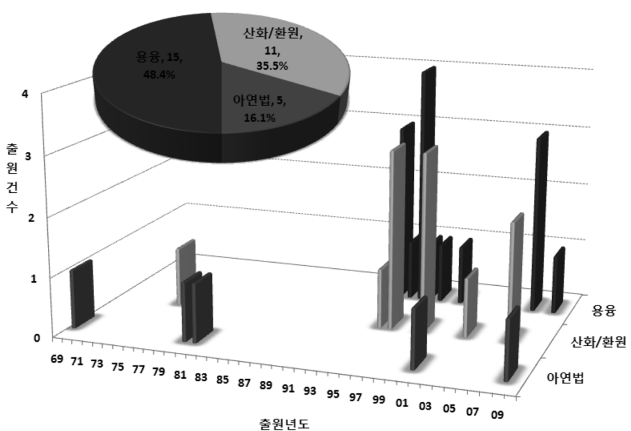

(a) patent

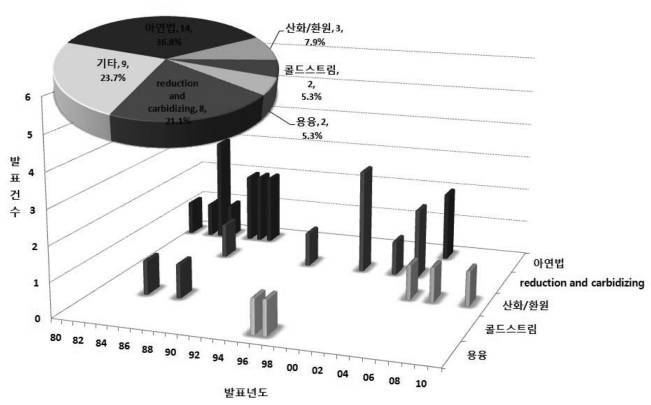

(b) paper

Fig. 8. A trend of patents and papers yearwise in each pyrometallurgical technology.

하였다.

독일의 H.C. Starck가 8 건으로 가장 많은 특허를 출원하였고, 미국의 Nanodyne Inc.이 4건, 캐나다의 International Carbitech Industries가 3건, 일본의 Fuji Seisakusho, 공주대학교가 각각 2건의 순으로 나타났다. 주요출원인 10 위까지의 출원인 중 한국이 4 개 기관으로 가장 많았으며 미국이 3 개 기관, 독일, 캐나다, 일본이 1 개 기관으로 확인되었다. 반면 논문의 경우 우크라이 나의 National Academy of Sciences of Ukraine가 7 건으로 가장 많은 논문을 발표하였고, 미국의 Teledyne Advanced Materials가 4건, 일본의 Iwate University, 오스트리아의 Vienna University of Technology가 각 각 3 건의 순으로 나타났다. 상위 10 위권 내의 발표기관 을 살펴보면 일본이 4개 기관으로 가장 많았으며 우크 라이나, 미국, 오스트리아, 영국, 이탈리아, 핀란드가 1 개 기관으로 확인되었다

가장 많은 특허를 출원한 H.C. Starck은 산화/환원,

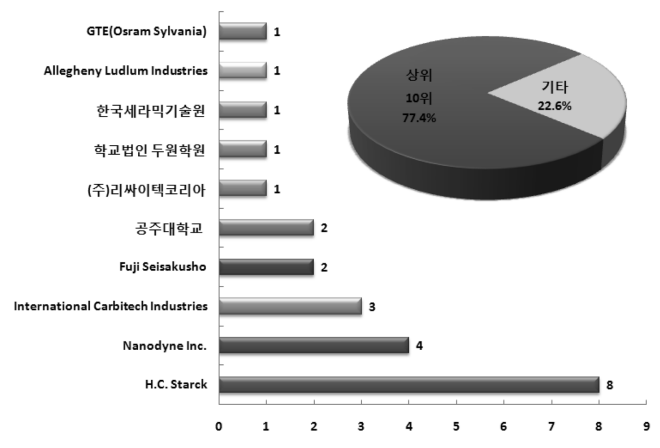

(a) patent

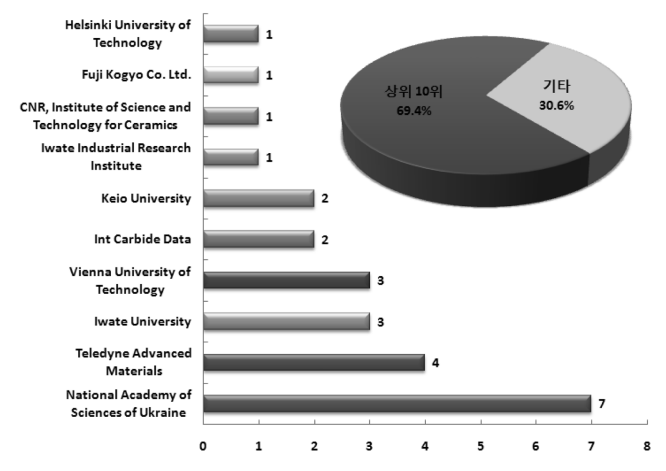

(b) paer

Fig. 9. Number and share of patents and papers in pyrometallurgy by the applicant.

Nanodyne Inc.은 용융 기술에 많은 특허를 출원하였으 며, National Academy of Sciences of Ukraine는 reduction and carbidizing 기술, Teledyne Advanced Materials는 아연법 기술, Vienna University of Techno$\operatorname{logy}$ 는 용융 기술에 많은 논문을 발표하였다.

\section{3. 핵심특허 및 논문 분석}

Table 4에 텅스텐카바이드(WC) 재활용 기술에 대한 핵심특허와 논문을 정리하여 나타내었다. 매장량이 적 기 때문에 고가이며 전략적인 금속으로 알려진 텅스텐 $(\mathrm{W})$ 과 코발트 $(\mathrm{Co})$ 를 주성분으로 하는 텅스텐카바이드 (WC) 재활용이 필요하지만, 일반적으로 텅스텐카바이드 는 고융점 및 고강도의 소결체이므로 종래의 물리적 화 학적 방법으로는 재생이 곤란하다. 그리고 환경문제 및 경제성 등의 문제 때문에 재활용하면 부가가치가 충분 한 산업폐기물임에도 불구하고 재활용이 어려운 것으로 
Table 4. List of core patents and papers

\begin{tabular}{|c|c|c|c|}
\hline 중분류 & 특허번호/논문, Vol, Page & 공개(등록)일 & 출원인/저자 \\
\hline \multirow{17}{*}{ 습식 } & [US] 4349423 & 1982.09 .14 & SKF Industrial Trading \& Development \\
\hline & [US] 4533527 & 1985.08 .06 & Interox Chemicals Limited \\
\hline & [US] 4784688 & 1988.11 .01 & The Hydrogen Solar Production \\
\hline & [US] 20080226528 & 2008.09 .18 & Wild River Consulting Group, LLC \\
\hline & [US] 5728197 & 1998.03 .17 & Nanodyne Incorporated \\
\hline & [US] 20110048968 & 2011.03 .03 & Kohsei Co. Ltd. \\
\hline & [US] 6524366 & 2003.02 .25 & N.V. Union Miniere S.A. \\
\hline & [US] 6395241 & 2002.05 .28 & OM Group, Inc. \\
\hline & [US] 4140597 & 1979.02 .20 & Toho Kinzoli Co., Ltd. \\
\hline & [US] 4255397 & 1981.03 .10 & GTE(Osram Sylvania) \\
\hline & [US] 4385972 & 1983.05 .31 & GTE(Osram Sylvania) \\
\hline & $\begin{array}{l}\text { Transactions of Nonferrous Metals Society of } \\
\text { China } \\
\text { Vol. 16, Page. } 687 \sim 692\end{array}$ & 2006 & Luo L., Wei J.-H., Wu G.-Y., Toyohisa F., Atsushi S. \\
\hline & $\begin{array}{l}\text { Journal of Cleaner Production } \\
\text { Vol. } 43 \text {, Page. } 47-61\end{array}$ & 1996 & Lin J.-C., Lin J.-Y., Jou S.-P. \\
\hline & $\begin{array}{l}\text { Key Engineering Materials } \\
\text { Vol. } 280 \sim 283 \text {, Page. } 1479 \sim 1484\end{array}$ & 2005 & Gao N., Inagaki F., Sasai R., Itoh H., Watari K. \\
\hline & $\begin{array}{l}\text { Journal of the Electrochemical Society } \\
\text { Vol. 127, Page. 2144 } 2147\end{array}$ & 1980 & Ghandehari M.H. \\
\hline & $\begin{array}{l}\text { World of Metallurgy - ERZMETALL } \\
\text { Vol. 57, Page. } 143 \sim 147\end{array}$ & 2004 & Gurmen S., Friedrich B. \\
\hline & $\begin{array}{l}\text { Hydrometallurgy } \\
\text { Vol. } 76 \text {, Page. } 63 \sim 71\end{array}$ & 2005 & $\begin{array}{l}\text { Edtmaier C., Schiesser R., Meissl C., Schubert } \\
\text { W.D., Bock A., Schoen A., Zeiler B. }\end{array}$ \\
\hline \multirow{4}{*}{ 건식 } & [US] 5993756 & 1999.11.30 & H.C. Starck, GmbH \& Co. KG \\
\hline & [US] 5613998 & 1997.03.25 & Nanodyne Incorporated \\
\hline & [US] 4338126 & 1982.07 .06 & GTE(Osram Sylvania) \\
\hline & $\begin{array}{l}\text { International Journal of Refractory Metals and } \\
\text { Hard Materials } \\
\text { Vol. 14, Page. } 263 \sim 270\end{array}$ & 1996 & $\begin{array}{l}\text { Venkateswaran S., Schubert W.-D., Lux B., } \\
\text { Ostermann M., Kieffer B. }\end{array}$ \\
\hline \multirow{2}{*}{ 습식, 건식 } & [US] 20090255372 & 2009.10 .15 & H.C. Starck, GmbH \& Co. KG \\
\hline & [US] 5882620 & 1999.03 .16 & International Carbitech Industries, Inc. \\
\hline
\end{tabular}

알려져 있다. 그리고 폐기처리시 고철스크랩에 혼입되면 주철이나 제강제품에 악영향을 끼치게 된다. 따라서 폐 텅스텐카바이의 발생원과 회수하고자 하는 최종산물의 종류에 따라 적합한 재활용 기술이 적용되고 있으며, 주 요특허와 논문은 대부분이 acid leaching이나 전기분해 를 이용하여 텅스텐이나 코발트를 회수하는 기술이다. 습식기술 측면에 있어서 acid leaching이나 전기분해
를 이용하여 텅스텐이나 코발트 회수에 대한 특허와 논 문이 주를 이루고 있다. SKF Industrial Trading \& Development Co. B.V.는 hard metal scrap(텅스텐카바 이드와 binding metal)을 $\mathrm{HNO}_{3}$ 수용액에서 전기분해하 는 방법에 대한 특허를 미국에 등록하였고, 유럽 및 일 본에는 출원하였다. Interox Chemicals Limited는 과산 화수소용액과 산성용액(질산, 황산, 염산)을 이용하여 스

J. of Korean Inst. Resources Recycling Vol. 21, No. 1, 2012 
크랩으로부터 텅스텐을 회수하는 특허를 미국에는 등록 하였고, 유럽, 일본에는 출원하었다. Wild River Consulting Group, LLC는 텅스텐 원료로부터 텅스텐산 암모늄을 생성하는 하는 특허를 국제특허로 출원하여 공개되었으며 유럽, 미국, 일본에 출원하였다. Nanodyne Inc.는 텅스텐 카바이드와 코발트 나 텅스텐 함유 물질 을 고온산화 후, 산성용액 중에서 산 온침(acid digestion)하는 기술에 대한 특허를 미국에 등록하였고, 유럽, 한국, 일본에 출원하였다. N.V. Union Miniere S.A.는 tungsten oxide를 산용액에 용해시켜 불순물과 바인딩 물질을 분리하는 기술에 대해 국제특허를 출원 하여 공개하고, 미국에는 등록하였다. OM Group, Inc. 는 metal carbide scrap에서 alkali metal hydroxide를 이용하여 carbide metal을 회수하는 기술을 국제특허로 출원하여 공개되었고 미국에는 등록되었다.

Hunan Agricultural University의 Luo 등은 tungsten super alloy scrap을 PC88A를 이용하여 chloride solution에서 코발트와 니켈을 추출하는 논문을 발표하 였으며, National Central University의 Lin 등은 cemented tungsten carbide scrap을 산용액 중에서 전 기분해 하여 코발트와 텅스텐을 회수하는 논문을 발표 하였다. Nagoya University의 Gao 등은 WC-Co cermet을 nitric acid $\left(\mathrm{HNO}_{3}\right)$ 를 이용하여 hydrothermal oxidation기술로 텅스텐카바이드와 코발트 재생하는 논문 을 발표하였다. Fansteel Inc.의 Ghandehari는 전기분해로, Istanbul Technical University의 Gurmen 등과 Vienna University of Technology의 Edtmaier 등은 acid leaching으로 텅스텐카바이드 재활용에 대한 논문을 발표하였다.

건식기술 측면에 있어서는 용융이나 아연법등을 이용 하여 텅스텐이나 코발트를 회수하는 특허와 논문이 주 를 이루고 있다. H.C. Starck, $\mathrm{GmbH} \&$ Co. KG는 $\mathrm{NaOH} 60$ 내지 90 중량 \% 및 $\mathrm{Na}_{2} \mathrm{SO}_{4} 10$ 내지 40 중 량 $\%$ 로 구성되는 용융염 중에서 경질합금 파철 및(또는) 중금속 파철을 산화시킴으로써 텅스텐산나트륨을 제조 하는 기술에 대해, 국제특허를 출원하여 공개되었으며 유럽, 미국, 한국, 일본에서 출원 공개되고 있다. Nanodyne Inc.는 텅스텐 조성물을 산화/환원을 이용한 재생 방법에 대한 기술로 미국에 특허를 등록되었으며 일본, 한국에 출원하였다. GTE(Osram Sylvania)는 heavy metal alloys를 아연을 이용하여 텅스텐을 회수 하는 기술에 대해 미국에 특허를 등록하였다. Vienna University of Technology의 Venkateswaran 등은 heavy metal hard scrap을 Menstruum Process를 이용
하여 텅스텐카바이드를 회수하는 논문을 발표하였다.

\section{6. 결론 및 향후 전망}

본 연구에서는 텅스텐카바이드(WC)의 재활용 기술에 대한 특허와 논문을 분석하였고, 텅스텐카바이드(WC) 의 재활용 방법에 대한 핵심특허와 논문 내용을 분석한 결과는 다음과 같다.

특허와 논문 모두 처음 출원이나 발표된 이후 최근까 지 증가와 감소를 반복적으로 나타나고 있다. 특허의 경 우, 초기에는 습식기술에 관한 특허가 대부분이었으나 1990년대 중반이후 습식과 건식기술 모두 다수의 특허 가 출원되고 있다. 논문의 경우, 초기에는 건식기술에 관한 논문이 대부분이었으나 시간이 흐를수록 습식기술 에 관한 논문이 많이 발표되고 있다.

국가별로는 미국과 일본이 해당 기술을 주도하고 있 다. 한국이 특허에서는 3 위로 나타나고 있지만 논문의 경우 미국, 일본에 비해 매우 낮은 점유율을 나타내고 있다. 우크라이나와 러시아의 경우 특허출원 현황은 나 타나고 있지 않지만 논문발표에서 높은 점유율을 나타 내고 있다.

기술별로는, 특허의 경우 습식 기술이 높은 점유율을 보였지만 한국의 경우 습식 기술과 건식 기술에 대해 유사한 점유율을 보이고 있는 것으로 확인되었다. 논문 의 경우 습식 기술과 건식 기술에 대해 유사한 점유율 을 보이고 있다.

핵심특허 및 논문을 살펴보면 습식 기술의 경우, acid leaching이나 전기분해를 이용하여 텅스텐이나 코 발트의 회수에 대한 특허와 논문이 주를 이루고 있으며 건식 기술의 경우에는 용융이나 아연법 등을 이용하여 텅스텐이나 코발트를 회수하는 특허와 논문이 주를 이 루고 있다.

최근까지 텅스텐카바이드의 재활용에 대한 특허출원 과 논문발표는 꾸준히 있어 왔으나 실질적으로는 상업 적으로 크게 활발한 상태는 아니었다. 2005년 이후 중 국정부의 새로운 정책인 수출허가제의 도입으로 인해 국제시장에서 텅스텐의 가격이 급격하게 오름에 따라 텅스텐 자원의 재활용 문제가 새롭게 부각되고, 재활용 에 대한 관심도 점차 높아져 왔다. 국내에서는 알칼리 염에 의한 용융법이나 산처리법으로 재활용하는 방법이 상용화 되어 있다. 그러나 이 방법은 폐가스 및 폐수처 리 문제, 그리고 고온에서 분해가 진행되기 때문에 처 리비용이 과다하게 요구되는 문제점을 안고 있다. 이러 
한 이유로 향후 환경문제 및 처리비용 절감과 원료의 원활한 수급을 위해서 새로운 텅스텐카바이드 스크랩의 처리방법이 요구된다.

\section{감사의 글}

본 연구는 지식경제부의 재원으로 한국에너지기술평 가원의 지원을 받아 수행한 연구과제(2008-K012-01)인 “도시광석으로부터 희유금속의 순환활용 신기술개발"을 수행하여 얻은 결과의 일부이며 이에 감사드립니다.

\section{References}

1. 이우상, 2009 : “텅스텐카바이드 초경 슬러지의 리싸이클
링에 관한 연구" , 국민대학교 공학석사 학위논문

2. 이길근, 하국현, 2005 : $W C / C o$ 초경 스크랩 산화물의 고체탄소에 의한 환원/침탄, 한국분말야금학회지, 12(2), pp112-116

3. 정은, 1986 : 초경합금 스크랩 재생, 대한금속재료학회지, 24(12), pp1342-1345

4. 김지혜, 2010 : “WC-Co系 超硬合金 加功슬러지로부터 코 발트 浸出 및 텅스텐 回收研究”, 대전대학교 공학석사 학 위논문

5. 허성중, 박수홍, 2006: 폐칩 재활용에 의한 내마모용 초경 합금 및 그 제조 방법, 한국특허, 10-0630950

6. 이종대, 박영효, 이태진, 2003 : 초경 scrap으로부터 텅스 텐 회수 및 촉매를 이용한 회수 텅스텐의 품질고급화 기 술개발, 공업화학전망, 6(3), pp39-47
鄭 鍧 己

• 현재 한국지질자원연구원 책임연구원

- 당 학회지 제 15 권 5 호 참조

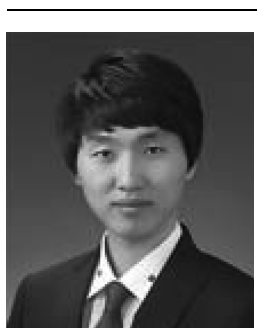

朴 相 友

•2009년 한밭대학교 학사

- 현재 주식회사 시온텍 사원

\section{李 在 天}

- 현재 한국지질자원연구원 책임연구원

- 당 학회지 제 10 권 6 호 참조

\section{姜 炅 碩}

- 현재 주식회사 시온텍 대표이사

- 당 학회지 제 16 권 3 호 참조 